3. Лазаренко К. А. Основи методики навчання іноземним мовам. Київ : Вища школа, 1997. 230 с.

4. Метьолкіна О. Б. Методичні рекомендації щодо організації індивідуального навчання аудіювання. Київ : Київський державний лінгвістичний університет, 1994. 65 с.

DOI https://doi.org/10.30525/978-9934-26-114-5-54

\title{
РОЗВИТОК ТВОРЧОГО ПОТЕНЦАЛУ МАЙБУТНІХ ЛІКАРІВ У ПРОФЕСІЙНІЙ ОСВІТІ
}

\author{
Мінухіна Д. В. \\ PhD, асистент кафедри внутрішньої медицини № 2 i клінічної \\ імунології та алергології імені академіка Л. Т. Малої \\ Харківський національний медичний університет \\ Мінухін Д. В. \\ кандидат медичних наук, доцент кафедри хірургї̈ № 1 \\ Харківський начіональний медичний університет \\ Свтушенко Д. О. \\ доктор медичних наук, професор кафедри хірургї̈ № 1 \\ Харківський національний медичний університет \\ м. Харків, Україна
}

Метою сучасної медичної освіти $\epsilon$ всебічний розвиток людини як особистості й найвищої цінності суспільства, іiї талантів, розумових і фізичних здібностей. У зв'язку з великою швидкістю змін у медицини зростає потреба суспільства у всебічній творчій активності сучасної людини, спроможної розв'язувати безліч різноманітних, в першу чергу медичних професійних завдань. Професія лікаря - одна 3 таких професій, що вимагає перманентного самовдосконалення та використання всіх розумових можливостей людини $[1,2]$.

Професійна підготовка майбутніх лікарів має бути орієнтована на формування не лише лікарської компетентності, а й готовності випускників до участі в забезпеченні гармонійного розвитку фізичних і духовних сил, високої працездатності й довголітнього активного життя громадян [1,3].

Актуальність теми обумовлюється також необхідністю визначення й експериментальної перевірки сукупності педагогічних умов, що забезпечать ефективне формування творчого потенціалу майбутніх 
лікарів та потребою самої особистості у використанні внутрішніх потенційних ресурсів для професійного зростання й самореалізації [1-3].

Мета дослідження полягала у теоретичному обгрунтуванні педагогічних умов формування творчого потенціалу майбутніх лікарів у процесі їх професійної підготовки.

Методи дослідження. Для досягнення мети дослідження, вирішення поставлених завдань використано сучасні методи: теоретичні - аналіз і синтез філософської, медичної та психологопедагогічної літератури з проблем розвитку особистості лікаря i професійної підготовки майбутніх фахівців; порівняння теоретичних аспектів щодо проблеми розвитку творчого потенціалу майбутніх лікарів та інші.

Результати, одержані в процесі діагностики складників творчого потенціалу у майбутніх лікарів забезпечили можливість поетапного конструювання процесу формування творчого потенціалу у студентівмедиків, визначили спрямованість на творчу діяльність, розвиток пошуково-творчого клінічного мислення, визначення індивідуального шляху реалізації творчого потенціалу. У процесі дослідження було 3'ясовано, що переважна більшість студентів молодших курсів виявила низький і середній рівень креативності та сформованості компонентів творчого потенціалу під час виконання навчальних завдань і в позааудиторній роботі.

3 метою кількісної перевірки ефективності вжитих заходів і впроваджених педагогічних умов здійснено порівняльний аналіз результатів констатувального і формувального експериментальних етапів нашого дослідження. Для цього проведено контрольний зріз стану сформованості трьох структурних компонентів творчого потенціалу у майбутніх лікарів експериментальної (Е) і контрольної (К) груп за тією самою методикою, яка була визначена для діагностичної роботи на констатувальному етапі педагогічного експерименту. За результатами контрольного етапу педагогічного експерименту, під час якого було проведено вторинне діагностування рівня сформованості майбутніх лікарів експериментальних і контрольних груп, отримано показники, що засвідчили ефективність упровадження визначених педагогічних умов.

В основі саморозвитку особистості майбутнього лікаря - процеси мотиваційної саморегуляції, мотивація професії в галузі медицини спрямовує i регулює навчальну діяльність студентів. Показники сформованості деонтологічного компонента в експериментальній групі мали такий вигляд: високий рівень - 56\%, середній - 43\%, 212 
низький $-1 \%$. У контрольній групі (К) високий рівень виявили $32 \%$ студентів, середній - 58\% респондентів, низький - $10 \%$ майбутніх лікарів, які не володіють механізмами творчого саморозвитку.

Показники сформованості мисленнєво-мовленнєвого компонента в експериментальній групі (Е) засвідчили позитивну динаміку зростання: високий рівень встановлено у $35 \%$ майбутніх лікарів, середній у $61 \%$, низький рівень - у 4\%. У контрольній групі (К) значних змін не зафіксовано: високий рівень виявлено у $20 \%$ респондентів; середній у $65 \%$ майбутніх лікарів; низький - у 15\% студентів. У багатьох учасників цих груп виявився низький ступінь саморегуляції творчої діяльності. Формування мисленнєво-мовленнєвого компонента творчого потенціалу майбутніх лікарів забезпечує розвиток творчого і клінічного мислення студентів-медиків, культури та психології спілкування, навичок ведення професійного діалогу; збагачення лексичного запасу загальновживаної і термінологічної лексики медичної галузі; володіння комунікативною компетентністю дає лікареві можливість: краще розпізнавати й правильно розуміти вербальні й невербальні ознаки спілкування з пацієнтами [1, с. 2].

Інноваційне мислення $\epsilon$ необхідним для успішної професійної діяльності, передбачає наявність в особистості творчого, креативного мислення. Людина $\epsilon$ творчою, якщо не повторює чи не наслідує когось або щось, хоча не завжди «нове» означає «творче». Розвиток це специфічний процес зміни, результатом якого $\epsilon$ виникнення якісно нового [2, с. $10 ; 3$, с. 315$]$.

Показники сформованості операційно-діяльнісного компонента в експериментальній групі (Е) також засвідчили результативність забезпечення педагогічних умов і позитивну динаміку: високий рівень встановлено у $30 \%$ майбутніх лікарів, середній у $65 \%$, низький рівень - у 5\%. У контрольній групі (К) зафіксовано такі результати: високий рівень виявлено у $20 \%$ респондентів; середній у $70 \%$ майбутніх лікарів; низький - у $10 \%$ студентів. 178 Формування операційно-діяльнісного компонента творчого потенціалу майбутніх лікарів зумовлює вдосконалення творчих і комунікативних умінь та навичок, сприяє розвитку творчого і клінічного мислення студентів, здатності генерувати нові ідеї, прогнозувати клінічну ситуацію; активізує потребу в творчому самовираження та готовність до професійної самореалізації.

Отже, в результаті впровадження формувальних заходів високий рівень розвитку творчого потенціалу було встановлено у $40 \%$ студентів 181 експериментальних груп (Е), середній - у 56\%, низький рівень - у $4 \%$ учасників експерименту. У контрольних групах високий рівень 
творчого потенціалу виявлено у 23\% респондентів; середній у $64 \%$; низький - у 13\% студентів. Середній рівень сформованості компонентів творчого потенціалу майбутніх лікарів характеризується зацікавленням творчими видами навчальної діяльності та власною участю в обміні інформацією, у створенні групових творчих проектів, але без прояву абсолютної самостійності, 3 певною пасивністю; намагання знайти аргументи, щоб довести власну думку; намаганням слухати і чути співрозмовника; здатністю знаходити компроміс, брати участь у рівноправному діалозі; точністю висловлювання. Для низького рівня сформованості компонентів творчого потенціалу майбутніх лікарів характерними є: бажання вислухати, але невміння почути i зрозуміти думку співрозмовника; розуміння творчої діяльності як як простого відтворювального виконання завдань; орієнтація на сприйняття зрозумілих ідей; відсутність творчого підходу до вирішення проблем й оригінальності думок; невміння (або небажання) будувати конструктивний діалог, встановлювати контакти; пасивність у діалозі; використання стандартних фраз. Оцінюючи рівні розвитку творчого потенціалу за трибальною шкалою - високий рівень набуває 3 бали у всіх випадках його встановлення у респондентів, середній - 2 бали, низький - 1 бал - одержали за результатами формувального експерименту показники, які наведено в таблиці

Висновки. 1. Уточнено сутність поняття «творчий потенціал майбутнього лікаря» як передумови саморозвитку й самореалізації особистості лікаря у подальшому розвитку професійних здібностей, індивідуального підходу й бачення хворого, здатності за допомогою клінічного мислення пізнавати саму сутність пацієнта. Клінічне мислення - це ключ до творчого вирішення інтелектуальних завдань лікування.

2. Поняття «творчий потенціал майбутнього лікаря» ми визначаємо як потенційну здатність до творчого саморозвитку, що виражається в активізації креативних можливостей особистості у продуктивній професійній діяльності й характеризується високим рівнем клінічного мислення, культурою діалогу, здатністю продукувати нові ідеї в галузі медицини, прогнозувати ситуації в лікарняній практиці та приймати найоптимальніші рішення на основі здобутих медичних знань, умінь, навичок та особливих професійних здібностей.

3. Встановлено, що показниками творчого потенціалу майбутнього лікаря є: творче клінічне мислення, творчо усвідомлені професійні знання, прагнення до новизни, стійка мотивація на творчий саморозвиток. 


\title{
Література:
}

1. Агаркова А. О. Формування професійно-етичної культури майбутніх лікарів у вищих навчальних закладах : автореф. дис ... канд. пед. наук: 13.00.07 / А. О. Агаркова. - Київ, 2011. - 22 с.

2. Кульбашна Я. А. Формування професійної компетентності майбутніх фахівців із стоматології: теоретичні й методичні основи : монографія / Я. А. Кульбашна ; Інститут вищої освіти Національної академії педагогічних наук України, Національний медичний університет імені О. О. Богомольця. - Київ : Компас, 2014. - 415 с.

3. Подласый И. П. Педагогика: 100 вопросов - 100 ответов: учебное пособие для вузов / И. П. Подласый. - М.: ВЛАДОС-пресс, 2004. -365 c.

DOI https://doi.org/10.30525/978-9934-26-114-5-55

\section{ВИКОРИСТАННЯ ДИСТАНЦЙНИХ ПЛАТФОРМ ТА ОНЛАЙН-СЕРВІСІВ В УМОВАХ ВІДДАЛЕНОГО НАВЧАННЯ ІНОЗЕМНОЇ МОВИ В НЕМОВНИХ ЗВО}

\author{
Мірошниченко Г. В.
}

старший викладач кафедри іноземних мов

Національний аерокосмічний університет імені М. С. Жуковського «Харківський авіаційний інститут»

Опаріна C. B.

старший викладач кафедри іноземних мов

Національний аерокосмічний університет імені М. С. Жуковського

«Харківський авіаційний інститут» м. Харків, Україна

На сьогоднішній день у зв'язку 3 ситуацією в світі система дистанційного навчання набула особливої актуальності. Загальна доступність Інтернету i простота його використання сприяли досить швидкому переходу ЗВО на дистанційне навчання в умовах оголошеного по всьому світу карантину. Дистанційне навчання також розглядають і як форму, і як одну зі складових всієї системи освіти, за якої взаємодія викладача і студентів здійснюється на відстані i відображає всі властиві навчальному процесу компоненти (цілі, зміст, методи, організаційні форми, засоби навчання), реалізовані специфічними засобами Інтернет-технологій [1]. 